\title{
Long-term Trends in Fertility of Soils Under Continuous Cultivation and Cereal Cropping in Southern Queensland. VIII* Available Nitrogen Indices and their Relationships to Crop Yield and N Uptake
}

\author{
R. C. Dalal and R. J. Mayer \\ Queensland Wheat Research Institute, \\ Department of Primary Industries, Toowoomba, Qld 4350.
}

\begin{abstract}
Six major soil series of southern Queensland were studied for the changes in the levels of available $\mathrm{N}$ indices (determined by both biological and chemical methods) and nitrate- $\mathrm{N}$, with continuous cultivation and cereal cropping for up to 70 years. The biological $\mathrm{N}$ indices, measured in soil collected at planting of winter cereals, were anaerobic mineralizable $\mathrm{N}$, aerobic mineralizable $N$ and nitrate- $N$ down to $1.2 \mathrm{~m}$ depth. The chemical indices were autoclave $\mathrm{N}$ and oven $\mathrm{N}$. The predictive capabilities of various available $\mathrm{N}$ indices, and total $\mathrm{N}$ and organic $\mathrm{C}$, were assessed from dry matter and $\mathrm{N}$ uptake of winter cereals in the field in 1983 as well as in the glasshouse.

Anaerobic mineralizable $\mathrm{N}$ levels increased with mean annual rainfall but decreased with mean annual temperatures of the sampling sites of the six soil series. Therefore, it was possible to predict closely anaerobic mineralizable $\mathrm{N}$ from soil total $\mathrm{N}$, and mean annual rainfall and temperature. Autoclave $\mathrm{N}$ showed no such trends.

Anaerobic mineralizable $\mathrm{N}$ declined with period of cultivation, exponentially in Waco, Langlands-Logie and Cecilvale soils $\left(0.112,0.111\right.$ and 0.247 year $^{-1}$, respectively) and linearly in the other three soil series. No consistent trends were discerned in autoclave $\mathrm{N}$ and oven $\mathrm{N}$ in four of the soil series with period of cultivation. Generally, nitrate- $N$ (measured at planting) declined with period of cultivation. However, in Billa Billa soil, it increased in the soil profile $(0-1 \cdot 2 \mathrm{~m})$ during the initial 7 years of cultivation and declined rapidly after 12 years.

Although a number of avallable $\mathrm{N}$ indices, including total $\mathrm{N}$ and organic $\mathrm{C}$, were significantly correlated with crop dry matter yield and $\mathrm{N}$ uptake, the best prediction of crop performance was provided by a combination of anaerobic mineralizable $\mathrm{N}(0-0.3 \mathrm{~m})$ and nitrate- $\mathrm{N}(0-0.6 \mathrm{~m})$ in the six soil series.
\end{abstract}

\section{Introduction}

Continuous cultivation and cereal cropping generally leads to reduced organic matter level in soil (Haas et al. 1957). The loss of nutrient-supplying capacity, especially nitrogen, could even be proportionally greater than the loss of total organic matter. For example, Campbell and Souster (1982) found that loss of potentially mineralizable $\mathrm{N}$, a measure of nitrogen-supplying capacity of soil, was greater than that of organic $\mathrm{C}$ or total $\mathrm{N}$ upon cropping of chernozemic soils. Dalal and Mayer $(1987 b)$ found that, for most southern Queensland soils, nitrogen mineralization potential (Stanford and Smith 1972) did not provide a significantly more sensitive index of soil fertility degradation due

\footnotetext{
* Part Vll, Aust. J. Soil Res., 1987, 25, 461-72.
} 
to cultivation than that shown by total soil $\mathrm{N}$ loss. The overall decline in anaerobic mineralizable $N$, a biological index of available $N$ (Keeney 1982), however, was proportionally much larger than that of organic $\mathrm{C}$ or total $\mathrm{N}$ in these soils after 20-70 years of cultivation for cereal cropping (Dalal and Mayer $1986 a$ ). Other available $\mathrm{N}$ indices include aerobic mineralizable $\mathrm{N}$, autoclave $N$ (chemical index) and nitrate- $N$ (Keeney 1982). Therefore, the objective of the present study was to compare the rates of loss in available $\mathrm{N}$ indices in six soil series due to cultivation and cropping for up to 70 years in southern Queensland. These indices were then compared with particle-size and light $C$ and $\mathrm{N}$ fractions, and total $\mathrm{N}$ and organic $\mathrm{C}$ (Dalal and Mayer 1986b, 1986c, $1987 a$ and $1987 b$ ) for their ability to predict responses in cereal crops, grown in the glasshouse as well as in the field.

\section{Materials and Methods}

The study area (between $27^{\circ}$ and $30^{\circ} \mathrm{S}$. and $148^{\circ}$ and $152^{\circ} \mathrm{E}$.), description of soils, cultural practices, and soil sampling and analytical techniques were described by Dalal and Mayer $(1986 a)$. The number of sampling sites of virgin and adjacent cultivated soils, respectively, were 5 and 16 in Waco soil series, 6 and 12 in Langlands-Logie soil series, 7 and 12 in Cecilvale soil series, 7 and 14 in Billa Billa soil series, 6 and 16 in Thallon soil series and 5 and 13 in Riverview soil series. The overall ranges in $\mathrm{pH}$ values, clay and organic $\mathrm{C}$ contents of the six soil series (0-0.1 m depth) from virgin sites were $6 \cdot 5-8 \cdot 1,19-74 \%$ and $0 \cdot 77-2 \cdot 23 \%$, respectively.

\section{Available Nitrogen Indices}

\section{Biological indices}

Anaerobic mineralizable $\mathrm{N}$. The amount of $\mathrm{NH}_{4}^{+}-\mathrm{N}$ produced in soil incubated under waterlogged conditions (Waring and Bremner 1964) at $40^{\circ} \mathrm{C}$ for 7 days was measured to provide a biological index of available $\mathrm{N}$ (Keeney 1982). Briefly, $5 \mathrm{~g}$ of soil, previously dried at $25^{\circ} \mathrm{C}$ and ground to $<2 \mathrm{~mm}$, was carefully poured into a tube (16 by $150 \mathrm{~mm}$ ) containing $12.5 \mathrm{ml}$ of deionized $\mathrm{H}_{2} \mathrm{O}$. The tube was stoppered and the submerged soil was incubated at $40^{\circ} \mathrm{C}$ for 7 days. Then the contents were transferred to a $100 \mathrm{ml}$ glass bottle by using three $12.5 \mathrm{ml}$ volumes of $2.67 \mathrm{M} \mathrm{KCl}$, shaken for $1 \mathrm{~h}$, filtered through Whatman No. 40 filter paper and the $\mathrm{NH}_{4}^{+}-\mathrm{N}$ in the filtrate was determined spectrophotometrically (Crooke and Simpson 1971). The amount of $\mathrm{NH}_{4}^{+}-\mathrm{N}$ present in the pre-incubated samples, usually $<2 \mathrm{mg} \mathrm{kg}^{-1}$ soil, was subtracted from that in the incubated soil to estimate anaerobic mineralizable $\mathrm{N}$.

Aerobic mineralizable $N$. Aerobic mineralizable $\mathrm{N}$ in soil was measured by the modified procedure of Stanford and Smith (1972) by incubating samples at $40^{\circ} \mathrm{C}$ for $2,4,8,12,16$, 22 and 30 weeks, as previously described (Dalal and Mayer $1987 \mathrm{~b}$ ). Since the amount of aerobic mineralizable $\mathrm{N}$ produced during the first 2 weeks of incubation may have been influenced by air-drying (Standford and Smith 1972), the mineral $\mathrm{N}$ produced after 4 weeks of incubation was taken as aerobic mineralizable $\mathrm{N}$.

\section{Chemical Indices}

\section{Autoclave $N$}

The amount of $\mathrm{NH}_{4}^{+}-\mathrm{N}$ produced by soil suspended in a solution of $0.01 \mathrm{M} \mathrm{CaCl}$ and autoclaved at $121^{\circ} \mathrm{C}$ for $16 \mathrm{~h}$ provided a chemical index of available $\mathrm{N}$ (Keeney 1982). Briefly, $5 \mathrm{~g}$ of air-dried soil, ground to $<2 \mathrm{~mm}$, was placed in a $28 \mathrm{ml}$ McCartney bottle, $12.5 \mathrm{ml}$ of $0.01 \mathrm{M} \mathrm{CaCl}_{2}$ solution was added and the contents were gently mixed. The bottle was stoppered and autoclaved for $16 \mathrm{~h}$ at $121^{\circ} \mathrm{C}$ and $101 \mathrm{kPa}$ pressure. After allowing the contents to cool to room temperature, $37.5 \mathrm{ml}$ of $2.67 \mathrm{M} \mathrm{KCl}$ was added, and the mixture was shaken for $1 \mathrm{~h}$. The contents of the bottle were then filtered and $\mathrm{NH}_{4}^{+}-\mathrm{N}$ was measured in the filtrate, as for anaerobic mineralizable $\mathrm{N}$. 


\section{Oven $N$}

This fraction was estimated as the amount of $\mathrm{NH}_{4}^{+}-\mathrm{N}$ produced when $3 \mathrm{~g}$ of air-dried, $<2 \mathrm{~mm}$ soil and $20 \mathrm{ml}$ of $2 \mathrm{M} \mathrm{KCl}$ were heated in a stoppered McCartney bottle in an oven at $100^{\circ} \mathrm{C}$ for $4 \mathrm{~h}$ (Gianello and Bremner 1986). After allowing the contents to cool to room temperature, $10 \mathrm{ml}$ of $2 \mathrm{M} \mathrm{KCl}$ was added and the mixture was shaken for $1 \mathrm{~h}$. The contents were filtered through a Whatman No. 40 paper, and $\mathrm{NH}_{4}^{+}-\mathrm{N}$ in the filtrate was determined as before.

\section{$\mathrm{NO}_{3}^{-}-\mathrm{N}$ and total $\mathrm{N}$}

Nitrate- $\mathrm{N}$ in soil was measured in $2 \mathrm{M} \mathrm{KCl}$ extracts (Best 1976) and total $\mathrm{N}$ in soil was determined by the Kjeldahl method, modified to include $\mathrm{NO}_{3}^{-}-\mathrm{N}$ (Dalal et al. $1984 \mathrm{~b}$ ).

All availability indices, except aerobic mineralizable $\mathrm{N}$, were estimated in soil samples collected from $0-0 \cdot 1,0 \cdot 1-0 \cdot 2,0.2-0 \cdot 3,0 \cdot 3-0 \cdot 6,0 \cdot 6-0.9$ and $0.9-1 \cdot 2 \mathrm{~m}$ layers. These were calculated on an oven-dry weight basis. Using bulk density and equivalent soil weight-soil depth relationships (Dalal and Mayer 1986b), $\mathrm{N}$ values were calculated on a soil volume basis. Aerobic mineralizable $\mathrm{N}$ was estimated in soll samples collected from the $0-0.1 \mathrm{~m}$ layer only.

\section{Crop Yields and Nitrogen Uptake}

\section{Glasshouse experiment}

Wheat (Triticum aestivum L., cv. Hartog), four plants in each pot, was grown for 80 days in $0.15 \mathrm{~m}$ diameter plastic-lined pots, each containing a similar volume of soil $(1 \cdot 5-2 \cdot 5 \mathrm{~kg}$ air-dried soil). Soil water was adjusted to field capacity regularly. The soil samples collected from $0-0 \cdot 1,0 \cdot 1-0.2$ and $0.2-0.3 \mathrm{~m}$ layers only were used to estimate dry matter yields and $\mathrm{N}$ uptake.

\section{Field experiment}

The dry matter and grain yields and $\mathrm{N}$ uptake by winter crops were measured in 1983 when winter rainfall, April-September inclusive, was approximately twice the mean for the study area. For example, in Dalby, Queensland, one of the study areas, $490 \mathrm{~mm}$ of rainfall was received during this period against mean winter rainfall of $223 \mathrm{~mm}$. Plant samples of winter crops, mainly wheat and barley, were collected from cultivated areas where soil samples had been obtained, by harvesting 10 quadrats $\left(0.5 \mathrm{~m}^{2}\right.$ each) at maturity. Dry matter yields were obtained by drying the plant samples at $80^{\circ} \mathrm{C}$ for $24-48 \mathrm{~h}$. Grain and straw were then separated, weighed, ground to pass a $1 \mathrm{~mm}$ sieve and stored in sealed plastic containers.

Plant samples from both glasshouse and field experiments were analysed for $\mathrm{N}$ by digesting the samples in concentrated $\mathrm{H}_{2} \mathrm{SO}_{4}$ containing $\mathrm{K}_{2} \mathrm{SO}_{4}, \mathrm{CuSO}_{4} .5 \mathrm{H}_{2} \mathrm{O}$, and magnesium stearate, then determining $\mathrm{NH}_{4}^{+}-\mathrm{N}$ in the acid digest by the spectrophotometric method of Crooke and Simpson (1971).

\section{Statistical Analysis}

Available $\mathrm{N}$ indices were corrected for changes in bulk density with the period of cultivation (Dalal and Mayer $1986 \mathrm{~b}$ ), and the trends with period of cultivation were estimated using exponential regression when regression coefficients were significant at $P<0.05$ (Draper and Smith 1966), otherwise alternative linear or quadratic regression models were used.

Dry matter yield and $\mathrm{N}$ uptake in the pot experiment were regressed against available $\mathrm{N}$ indices and organic $\mathrm{C}$ using Mitscherlich, linear or quadratic equations, provided that the regression coefficients were significant. The field dry matter yield, grain yield and total $\mathrm{N}$ uptake (after adjusting for site differences via covariates) were similarly related to available $\mathrm{N}$ indices (which were 'estimated' for the appropriate period of cultivation whenever the field yields were measured one year or more after soil sampling). 


\section{Results}

\section{Available Nitrogen Indices in Virgin Soils}

The amounts of anaerobic mineralizable $\mathrm{N}$ varied by as much as five times in $0-0.1 \mathrm{~m}$ soil layers and by ten times in the $0-1.2 \mathrm{~m}$ layers, among the six soil series, whereas autoclave $\mathrm{N}$ varied by only about two times throughout the profiles of these soils (Table 1). The proportion of total $\mathrm{N}$ as nitrate- $\mathrm{N}$ varied from $0.1 \%$ in the Cecilvale clay soils to $0.5 \%$ in Billa Billa loamy clays. Anaerobic mineralizable $\mathrm{N}$ as a proportion of total $\mathrm{N}$ was least in the Riverview sandy loams $(3 \cdot 2 \%)$ and it generally declined with depth in all soils, whereas the proportion of autoclave $N$ differed much less among soils $(5 \cdot 5-8 \cdot 3 \%)$ and it either remained similar (Waco) or increased with depth. Distribution of oven $\mathrm{N}$ was similar to that of autoclave $\mathrm{N}$, although it comprised a much smaller proportion of total $\mathrm{N}(1 \cdot 0-2 \cdot 5 \%)$ than the latter $(5 \cdot 9-9 \cdot 0 \%)$.

Table 1. Amounts of anaerobic mineralizable $\mathrm{N}$ and autoclave $\mathrm{N}$ in the $0-0 \cdot 1,0-0 \cdot 3$ and $0-1 \cdot 2 \mathrm{~m}$ soil layers

Meants.d. values from virgin sites

\begin{tabular}{|c|c|c|c|c|c|c|}
\hline \multirow[t]{2}{*}{$\begin{array}{l}\text { Soil series } \\
\text { (No. of sites) }\end{array}$} & \multicolumn{3}{|c|}{$\begin{array}{c}\text { Anaerobic mineralizable } \mathrm{N} \\
\qquad\left(\mathrm{kg} \mathrm{ha}^{-1}\right)\end{array}$} & \multicolumn{3}{|c|}{$\begin{array}{l}\text { Autoclave N } \\
\left(\mathrm{kg} \mathrm{ha}^{-1}\right)\end{array}$} \\
\hline & $0-0.1 \mathrm{~m}$ & $0-0.3 \mathrm{~m}$ & $0-1 \cdot 2 \mathrm{~m}$ & $0-0.1 \mathrm{~m}$ & $0-0.3 \mathrm{~m}$ & $0-1 \cdot 2 \mathrm{~m}$ \\
\hline Waco clay $(5)^{\mathrm{A}}$ & $105 \pm 20$ & $228 \pm 19$ & $432 \pm 14$ & $73 \pm 6$ & $172 \pm 10$ & $459 \pm 24$ \\
\hline $\begin{array}{l}\text { Langlands-Logie } \\
\text { clay }(6)^{\mathrm{B}}\end{array}$ & $119 \pm 9$ & $258 \pm 29$ & $410 \pm 34$ & $108 \pm 4$ & $273 \pm 7$ & $797 \pm 22$ \\
\hline Cecilvale clay $(7)^{\mathrm{B}}$ & $99 \pm 8$ & $207 \pm 28$ & $325 \pm 43$ & $82 \pm 6$ & $193 \pm 12$ & $466 \pm 47$ \\
\hline $\begin{array}{l}\text { Billa Billa loamy } \\
\text { clay }(7)^{\mathrm{B}}\end{array}$ & $61 \pm 10$ & $137 \pm 18$ & $212 \pm 15$ & $85 \pm 8$ & $219 \pm 36$ & $564 \pm 124$ \\
\hline Thallon clay $(6)^{\mathrm{B}}$ & $23 \pm 6$ & $60 \pm 15$ & $135 \pm 18$ & $51 \pm 8$ & $168 \pm 20$ & $517 \pm 29$ \\
\hline $\begin{array}{l}\text { Riverview sandy } \\
\text { loam }(5)^{C}\end{array}$ & $33 \pm 8$ & $40 \pm 8$ & $44 \pm 10$ & $66 \pm 6$ & $169 \pm 22$ & $416 \pm 88$ \\
\hline
\end{tabular}

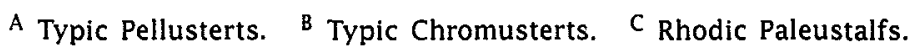

Over the six soil series, anaerobic mineralizable $\mathrm{N}$ was significantly correlated with mean annual rainfall $\left(r=0 \cdot 85^{*}\right)$ and temperature $\left(r=-0 \cdot 86^{*}\right)$, similar to that observed for total $\mathrm{N}$ (Dalal and Mayer 1986c). The effect of temperature on anaerobic mineralizable $N$, however, was greater than that observed on total $\mathrm{N}$, so that anaerobic mineralizable $\mathrm{N}$ as a proportion of total $\mathrm{N}$ declined with increasing mean annual temperature $\left(r=-0 \cdot 97^{* *}\right)$. Autoclave $N$, oven $\mathrm{N}$ and nitrate- $\mathrm{N}$ were not significantly correlated with either mean annual temperature or rainfall.

\section{Changes in Available Nitrogen Indices in Cultivated Soils}

The relationships between available $\mathrm{N}$ indices $(Y)$ and period of cultivation $(t)$ were described according to the exponential equation

$$
Y_{\mathrm{t}}=Y_{\mathrm{e}}+\left(Y_{0}-Y_{\mathrm{e}}\right) \exp (-k t),
$$

where $Y$ represents the index at time zero $\left(Y_{0}\right)$, at time $t\left(Y_{t}\right)$ or at equilibrium $\left(Y_{\mathrm{e}}\right)$ and $k$ is the rate of loss, year-1 (Fig. 1). The rates of loss ( $k$ values) 
in anaerobic mineralizable $\mathrm{N}$, aerobic mineralizable $\mathrm{N}$ and autoclave $\mathrm{N}$ with increasing period of cultivation of Waco soil were $0 \cdot 112 \pm 0 \cdot 037,0 \cdot 208 \pm 0.092$ and $0.056 \pm 0 \cdot 026$ year $^{-1}$; the respective half-lives $\left(t_{1 / 2}=\ln 2 / k\right)$ were $6 \cdot 2 \pm 2 \cdot 1$, $3 \cdot 3 \pm 1 \cdot 2$ and $12 \cdot 5 \pm 5 \cdot 9$ years, respectively.

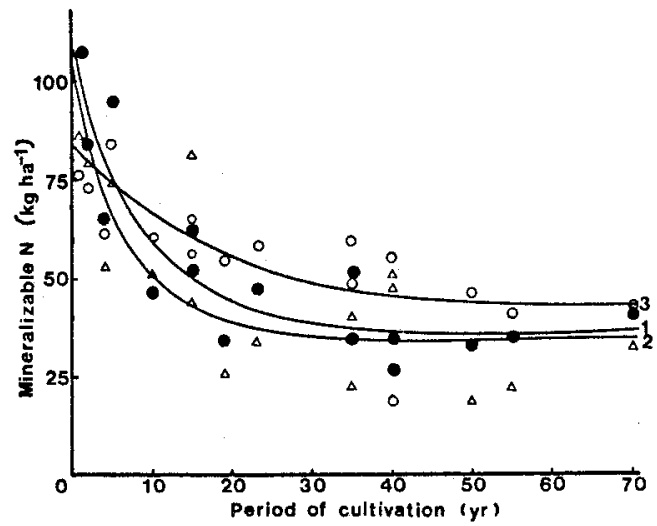

Fig. 1. Mineralizable $\mathrm{N}$ in relation to period of cultivation $(t)$ in $0-0.1 \mathrm{~m}$ depth of Waco soil, for: 1. anaerobic mineralizable $\mathrm{N}, Y_{1},(0) ; 2$. aerobic mineralizable $\mathrm{N}, Y_{2},(0) ; 3$. autoclave $N, Y_{3},(\Delta)$. The relevant equations are
1. $Y_{1}=37^{* *}+69^{* *} ; \exp \left(-0 \cdot 112^{* *} t\right), \quad n=21, R^{2}=0.84$;
2. $Y_{2}=35^{* *}+68^{* *} ; \exp \left(-0.208^{*} t\right), \quad n=21, R^{2}=0 \cdot 77^{*}$
3. $Y_{3}=41^{* *}+43^{* *} ; \exp \left(-0.056^{*} t\right), \quad n=21, R^{2}=0 \cdot 76$.

Table 2. Initial values $\left(Y_{0}\right)$, equilibrium values $\left(Y_{e}\right)$, rate of loss $(k)$ and half-life $\left(t_{1 / 2}\right)$ of anaerobic mineralizable $N$ at different depths in three soils

Meants.e. values are given

\begin{tabular}{|c|c|c|c|c|c|c|}
\hline $\begin{array}{c}\text { Soil } \\
\text { series }^{A}\end{array}$ & $\begin{array}{l}\text { Soil depth } \\
\text { (m) }\end{array}$ & $\begin{array}{c}Y_{0}{ }^{B} \\
\left(\mathrm{~kg} \cdot \mathrm{Nh} \mathrm{a}^{-1}\right)\end{array}$ & 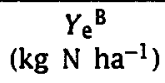 & $\begin{array}{c}k^{\mathrm{B}} \\
\left(\text { year }^{-1}\right)\end{array}$ & $\begin{array}{l}t_{1 / 2}{ }^{B} \\
\text { (year) }\end{array}$ & $R^{2}$ \\
\hline Waco & $\begin{array}{l}0-0 \cdot 1 \\
0-0 \cdot 2 \\
0-0 \cdot 3 \\
0-0 \cdot 6\end{array}$ & $\begin{array}{l}106 \pm 5 \\
185 \pm 8 \\
233 \pm 8 \\
342 \pm 11\end{array}$ & $\begin{array}{c}37 \pm 5 \\
63 \pm 9 \\
89 \pm 11 \\
151 \pm 29\end{array}$ & $\begin{array}{l}0.112 \pm 0.037 \\
0.093 \pm 0.026 \\
0.075 \pm 0.020 \\
0.042 \pm 0.016\end{array}$ & $\begin{array}{r}6 \cdot 2 \pm 2 \cdot 1 \\
7 \cdot 5 \pm 3 \cdot 0 \\
9 \cdot 2 \pm 2 \cdot 4 \\
16 \cdot 4 \pm 6 \cdot 0\end{array}$ & $\begin{array}{l}0.84 \\
0.88 \\
0.90 \\
0.87\end{array}$ \\
\hline $\begin{array}{l}\text { Langlands- } \\
\text { Logie }\end{array}$ & $\begin{array}{l}0-0 \cdot 1 \\
0-0 \cdot 2 \\
0-0 \cdot 3\end{array}$ & $\begin{array}{l}117 \pm 3 \\
203 \pm 8 \\
261 \pm 10\end{array}$ & $\begin{array}{c}47 \pm 5 \\
114 \pm 11 \\
159 \pm 13\end{array}$ & $\begin{array}{l}0.111 \pm 0.025 \\
0.135 \pm 0.058 \\
0.158 \pm 0.075\end{array}$ & $\begin{array}{l}6 \cdot 2 \pm 1 \cdot 4 \\
5 \cdot 1 \pm 2 \cdot 2 \\
4 \cdot 4 \pm 2 \cdot 1\end{array}$ & $\begin{array}{l}0.93 \\
0.79 \\
0.78\end{array}$ \\
\hline Cecilvale & $\begin{array}{l}0-0 \cdot 1 \\
0-0 \cdot 2\end{array}$ & $\begin{array}{l}100 \pm 3 \\
162 \pm 6\end{array}$ & $\begin{array}{l}46 \pm 3 \\
84 \pm 7\end{array}$ & $\begin{array}{l}0.247 \pm 0.073 \\
0.194 \pm 0.082\end{array}$ & $\begin{array}{l}2 \cdot 8 \pm 0 \cdot 8 \\
3 \cdot 6 \pm 1 \cdot 5\end{array}$ & $\begin{array}{l}0.93 \\
0.84\end{array}$ \\
\hline
\end{tabular}

A Waco, Langlands-Logie and Cecilvale soils have been cultivated for 0-70, 0-45 and 0-35 years, respectively.

B $Y_{0}, Y_{\mathrm{e}}$ and $k$ were calculated according to equation (1), $t_{1 / 2}=\ln 2 / k$.

Significant rates of decline of anaerobic mineralizable $\mathrm{N}$ occurred up to $0.6 \mathrm{~m}$ depth in the Waco soils, $0.3 \mathrm{~m}$ depth in the Langlands-Logie soils and $0.2 \mathrm{~m}$ depth in the Cecilvale soils (Table 2). In the Waco and Cecilvale soils, the $k$ values decreased with depth, whereas those in the Langlands-Logie soils were essentially similar at different depths. 
The exponential equation (1) did not apply [that is, the regression coefficients were not significantly different from zero at $P<0.05$ (Draper and Smith 1966)] to the changes in available $\mathrm{N}$ indices with period of cultivation in Billa Billa, Thallon and Riverview soils, and to those of oven $\mathrm{N}$ and $\mathrm{NO}_{3}^{-}-\mathrm{N}$ in all soil layers as well as to all available $\mathrm{N}$ indices in deeper layers of all soils. In these cases, linear $\left(Y_{t}=Y_{0}+a_{1} t\right)$ or quadratic $\left(Y_{t}=Y_{0}+a_{1} t+a_{2} t^{2}\right)$ equations were used, where $a_{1}$ and $a_{2}$ are regression coefficients.

Anaerobic mineralizable $N$ declined (only $R^{2} \geq 0.5$ values are considered) at the rate of $3 \cdot 65 \pm 0 \cdot 38,3 \cdot 34 \pm 0 \cdot 69,2 \cdot 73 \pm 0 \cdot 61,2 \cdot 24 \pm 0 \cdot 58$ and $0 \cdot 93 \pm 0 \cdot 20 \mathrm{~kg} \mathrm{ha}^{-1} \mathrm{yr}^{-1}$ in Waco $(0-1 \cdot 2 \mathrm{~m})$, Langlands-Logie $(0-1 \cdot 2 \mathrm{~m})$, Cecilvale $(0-0.3 \mathrm{~m})$, Billa Billa $(0-0.3 \mathrm{~m})$ and Thallon $(0-0.2 \mathrm{~m})$ soils, respectively. No trend could be discerned for autoclave $N$ or oven $N$ in these soils, except in Riverview soil where oven $N$ declined at the rate of $1 \cdot 39 \pm 0.29 \mathrm{~kg} \mathrm{ha}^{-1} \mathrm{yr}^{-1}$ $(0-0.3 \mathrm{~m})$.

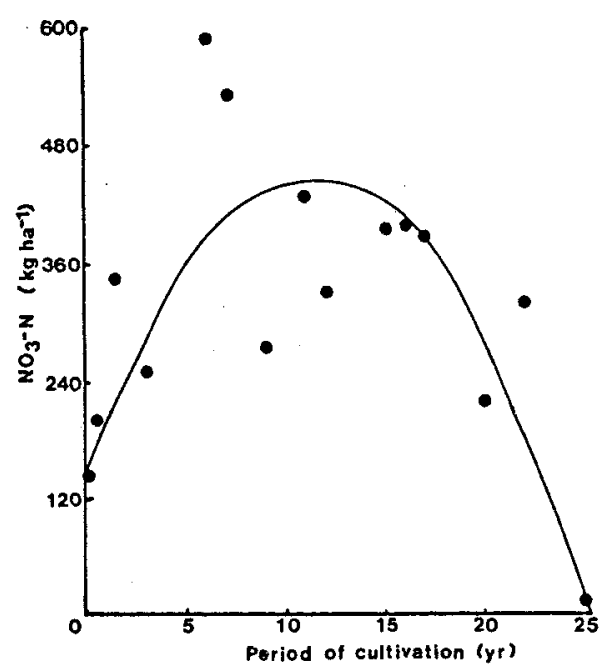

Fig. 2. Nitrate-N ( $Y$ ) in 0-1.2 $\mathrm{m}$ depth of Billa Billa soil in relation to period of cultivation (t). The relevant equation is

$$
Y=146 \cdot 8+53 \cdot 3^{* *} t-2 \cdot 3^{* *} t^{2}, \quad R^{2}=0.62 .
$$

Nitrate- $\mathrm{N}$ content in Waco and Langlands-Logie soils showed no trend with the period of cultivation. However, it declined up to $1.2 \mathrm{~m}$ depth from

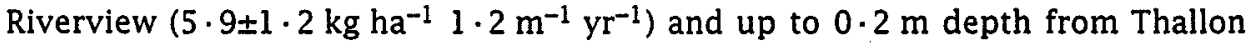
soils $\left(0.4 \pm 0.1 \mathrm{~kg} \mathrm{ha}^{-1} 0.2 \mathrm{~m}^{-1} \mathrm{yr}^{-1}\right)$. On the other hand, in Billa Billa soils, it increased in the soil profile (0-1.2 $\mathrm{m}$ depth), mostly at 0.6-1.2 $\mathrm{m}$ depth, for the first 7 years, then declined to a low level after 25 years of cultivation (Fig. 2).

\section{Crop Yields and Nitrogen Uptake}

\section{Pot experiment}

Dry matter yields were closely correlated with $\mathrm{N}$ uptake at the three depths studied in six soil series $\left(r=0.93^{* *}, n=357\right)$.Nitrogen uptake from plants grown 
Table 3. Anaerobic mineralizable $\mathrm{N}$ and total nitrogen levels required for $90 \%$ of maximum yield

\begin{tabular}{lccc}
\hline $\begin{array}{c}\text { Plant } \\
\text { parameters }\end{array}$ & \multicolumn{2}{c}{ Anaerobic min. $\mathrm{N}\left(\mathrm{kg} \mathrm{ha}^{-1}\right)$} & Total N $\left(\mathrm{kg} \mathrm{ha}^{-1}\right)$ \\
$0-0.1 \mathrm{~m}$ & $0-0.3 \mathrm{~m}$ & $0-0.1 \mathrm{~m}$ \\
\hline & \multicolumn{1}{c}{ Field experiment $(n=39)$} \\
Dry matter yield & $47(0.61)^{\mathrm{A}}$ & $151(0.84)^{\mathrm{A}}$ & $1045(0.68)^{\mathrm{A}}$ \\
Grain yield & $74(0.47)^{\mathrm{B}}$ & $152(0.64)^{\mathrm{B}}$ & $1056(0.59)^{\mathrm{A}}$ \\
Total N uptake & $75(0.60)^{\mathrm{B}}$ & $156(0.77)^{\mathrm{B}}$ & $1196(0.65)^{\mathrm{B}}$ \\
& Pot experiment $(n=119)$ & \\
Dry matter yield & $94(0.47)^{\mathrm{B}}$ & $169(0.48)^{\mathrm{B}}$ & $1582(0.50)^{\mathrm{B}}$ \\
Total N uptake & $82(0.62)^{\mathrm{B}}$ & $166(0.62)^{\mathrm{B}}$ & $1535(0.59)^{\mathrm{B}}$ \\
\hline
\end{tabular}

A Values in parentheses are the $R^{2}$ values obtained between plant parameters $(y)$ and anaerobic mineralizable $\mathrm{N}$ or total $\mathrm{N}(x)$ from the exponential relationship $y=b_{0}-b_{1} \exp (-c x)$, where $b_{0}$ is maximum yield, and $b_{1}$ and $c$ are constants.

${ }^{\mathrm{B}} R^{2}$ values obtained from the quadratic relationship $y=a x^{2}+b x+c$, where $a$ and $b$ are constants; when $y$ is maximum, $x=-b / 2 a$.

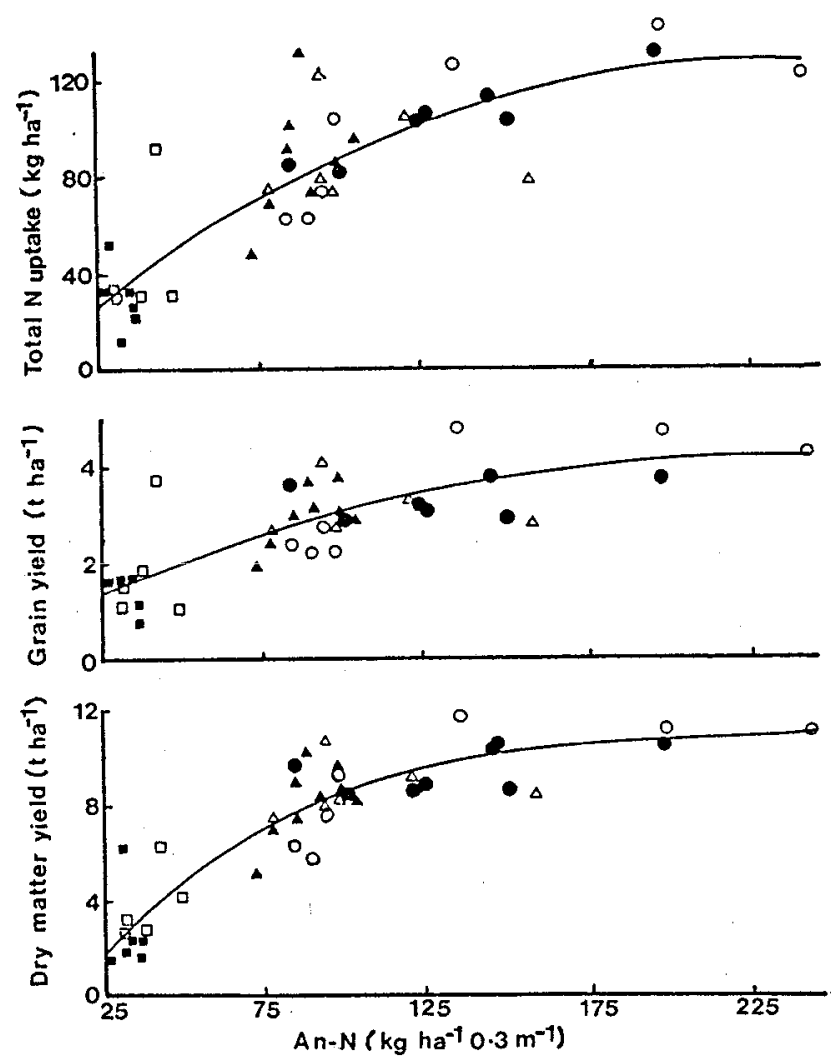

Fig. 3. Relationship between anaerobic mineralizable $N($ An- $N)(x)$ and dry matter yield $(D M)$, grain yield (GY) and total $N$ uptake (NU). Symbols represent Waco (O), Langlands-Logie $(\bullet)$, Cecilvale $(\Delta)$, Billa Billa $(\Delta)$, Thallon $(\square)$ and Riverview $(\square)$. The relevant equations are

$$
\begin{aligned}
& \mathrm{DM}=11 \cdot 2^{* *}-14 \cdot 2^{* *} \exp \left(-0.01688^{* *} x\right), \quad R^{2}=0.84, \\
& \mathrm{GY}=0.63+0.03^{* *} x-\left(6 \cdot 7 \times 10^{-5 * *}\right) \mathrm{x}^{2}, \quad R^{2}=0.64, \\
& \mathrm{NU}=-0.97+1 \cdot 14^{* *} x-0.0025^{* *} x^{2}, \quad R^{2}=0.77
\end{aligned}
$$


in the top $0.1 \mathrm{~m}$ soil from the virgin sites was in the order ( $\mathrm{mg} \mathrm{N} \mathrm{kg}^{-1}$ soil): Waco $(44 \cdot 6)>$ Billa Billa $(39 \cdot 7)>$ Langlands-Logie $(37 \cdot 6)>$ Cecilvale $(28 \cdot 0)>$ Thallon $(13 \cdot 5)>$ Riverview $(10 \cdot 7)$. This trend was generally followed at $0 \cdot 1-0 \cdot 2 \mathrm{~m}$ and $0 \cdot 2-0.3 \mathrm{~m}$ depths except that $\mathrm{N}$ uptake from Billa Billa soil at these two depths exceeded those from Waco and Langlands-Logie soils.

Plant $\mathrm{N}$ uptake from the top $0.1 \mathrm{~m}$ layer of all six soil series declined significantly upon cultivation (from $11 \%$ in Thallon soils to $37 \%$ in Billa Billa soils). Langlands-Logie and Billa Billa soils showed a greater decline in $\mathrm{N}$ uptake than other soils, not only from the top $0.1 \mathrm{~m}$ depth but also from $0 \cdot 1-0 \cdot 2 \mathrm{~m}$ and $0 \cdot 2-0.3 \mathrm{~m}$ depths.

Correlation coefficients between plant $\mathrm{N}$ uptake in the glasshouse experiment and available $\mathrm{N}$ indices, other soil $\mathrm{N}$ fractions (Dalal and Mayer 1986c, 1986d) and organic $C$, resulted in the following order of $r$ values (in parentheses) for $n=119,0-0.1 \mathrm{~m}$ depth of all soils: anaerobic mineralizable $\mathrm{N}(0.74)>$ total $\mathrm{N}$ $(0.72)>$ aerobic mineralizable $\mathrm{N}(0.68)>$ clay $\mathrm{N}(0.68)>$ organic $\mathrm{C}(0.66)>$ sand $\mathrm{N}(0.58)>\mathrm{N}$ mineralization potential, $N_{0},(0.55)>$ autoclave $\mathrm{N}\{0.54)>$ oven $\mathrm{N}(0 \cdot 54)>$ microbial biomass $-\mathrm{N}(0 \cdot 52)>\mathrm{NO}_{3}^{-}-\mathrm{N}(0 \cdot 50)$.

The prediction of plant $\mathrm{N}$ uptake from anaerobic mineralizable $\mathrm{N}$ and total $\mathrm{N}$ improved significantly when $\mathrm{NO}_{3}^{-} \mathrm{N}$ was considered together with available $\mathrm{N}$ indices $(n=119)$ :

$$
\begin{array}{r}
\text { Plant } \mathrm{N}=1 \cdot 8+0 \cdot 48^{*} \mathrm{NO}_{3}^{-}-\mathrm{N}+0 \cdot 48^{* *} \mathrm{An}-\mathrm{N} 16 \times 10^{-4 * *}(\mathrm{An}-\mathrm{N})^{2}, \\
\text { s.e. estimate }=6 \cdot 1, \quad R^{2}=0 \cdot 79 ; \\
\text { Plant } \mathrm{N}=-11 \cdot 4+0 \cdot 46^{*} \mathrm{NO}_{3}^{-}-\mathrm{N}+42 \cdot 0^{* *} \mathrm{TN}-85 \cdot 2^{* *}(\mathrm{TN})^{2}, \\
\text { s.e. estimate }=6 \cdot 7, \quad R^{2}=0 \cdot 75 ;
\end{array}
$$

where plant $\mathrm{N}$, anaerobic mineralizable $\mathrm{N}(\mathrm{An}-\mathrm{N})$ and $\mathrm{NO}_{3}^{-}-\mathrm{N}$ are expressed in $\mathrm{mg} \mathrm{kg}^{-1}$ soil, and total $\mathrm{N}$ (TN) is in $\mathrm{g} \mathrm{kg}^{-1}$ soil $(0-0.1 \mathrm{~m}$ depth).

Anaerobic mineralizable $\mathrm{N}$ and total $\mathrm{N}$ required for $90 \%$ of maximum yield were essentially similar for both dry matter yield and total $\mathrm{N}$ uptake (Table 3 ).

\section{Field experiment}

Among all the available $\mathrm{N}$ indices, only anaerobic mineralizable $\mathrm{N}$, aerobic mineralizable $\mathrm{N}$ and total $\mathrm{N}$ were significantly related to the 'site' adjusted dry matter, grain yield and total $\mathrm{N}$ uptake (Fig. 3 and Table 3 ). The association between the yield and anaerobic mineralizable $\mathrm{N}$ improved as the soil depth for the latter increased (Table 3); the reverse was the case for total N. Prediction of dry matter yield improved significantly when $\mathrm{NO}_{3}^{-}-\mathrm{N}$ at $0-0.6 \mathrm{~m}$ was included along with anaerobic mineralizable $\mathrm{N}$ :

$$
\begin{gathered}
\mathrm{DM}=-1093+121^{* *} \mathrm{An}-\mathrm{N}-0 \cdot 31^{* *}(\mathrm{An}-\mathrm{N})^{2}+0 \cdot 10^{*}\left(\mathrm{NO}_{3}^{-}-\mathrm{N}\right)^{2}, \\
\text { s.e. estimate }=1507, \quad R^{2}=0.86,
\end{gathered}
$$

where DM is field dry matter yield $\left(\mathrm{kg} \mathrm{ha}^{-1}\right)$, An-N is anaerobic mineralizable $\mathrm{N}$ and $\mathrm{NO}_{3}^{-} \mathrm{N}\left(\mathrm{kg} \mathrm{ha}^{-1}\right)$ in soil.

Anaerobic mineralizable $\mathrm{N}$ and total $\mathrm{N}$ required for $90 \%$ maximum yield were generally lower for field dry matter yield than total $\mathrm{N}$ uptake or grain yield (Table 3 ). 


\section{Discussion}

\section{Available Nitrogen Indices}

The available $\mathrm{N}$ indices considered in this study, although significantly correlated with each other, as in other studies (Smith and Stanford 1971), exhibited different rates of change with period of cultivation (Table 4). For example, in Waco soil, rates of loss of anaerobic and aerobic mineralizable $\mathrm{N}$ were 2-3 times greater than that of autoclave $\mathrm{N}$, but closer to those of nitrogen mineralization potential, clay-size $\mathrm{N}$, sand-size $\mathrm{C}$ and light fraction $\mathrm{N}$. The rate of loss of autoclave $N\left(0.056 \mathrm{yr}^{-1}\right)$ was essentially similar to that of total $\mathrm{N}\left(0.061 \mathrm{yr}^{-1}\right)$ and organic $\mathrm{C}\left(0.065 \mathrm{yr}^{-1}\right)$. However, in Langlands-Logie soil, the rates of loss of anaerobic mineralizable $\mathrm{N}$, aerobic mineralizable $\mathrm{N}$ and autoclave $\mathrm{N}$ were essentially similar to that of total $\mathrm{N}$. Therefore, it is unlikely that any one of the available $\mathrm{N}$ indices would reflect similarly the mineralizability or lability of organic $\mathrm{N}$ in a wide range of soils.

Table 4. Comparison of exponential rates of loss of mineralizable $N$ with that of organic $C$ and $N$ from different fractions in three soil series $(0-0.1 \mathrm{~m})$, expressed on $w / v$ basis

\begin{tabular}{|c|c|c|c|c|c|c|}
\hline \multirow[t]{3}{*}{ Fraction } & \multirow{2}{*}{\multicolumn{2}{|c|}{ Waco }} & \multicolumn{2}{|c|}{ Rate of loss $\left(\mathrm{yr}^{-1}\right)$} & \multirow{2}{*}{\multicolumn{2}{|c|}{ Cecilvale }} \\
\hline & & & Langlan & s-Logie & & \\
\hline & $\mathrm{N}$ & C & $\mathrm{N}$ & $\mathrm{C}$ & $\mathbf{N}$ & C \\
\hline \multicolumn{7}{|c|}{ Mineralizable $N$} \\
\hline Anaerobic $\mathrm{N}$ & 0.112 & & 0.111 & & 0.247 & \\
\hline Aerobic $N$ & $0.208^{F}$ & & n.s.G & & $0.193^{\mathrm{F}}$ & \\
\hline Autoclave $\mathrm{N}$ & 0.056 & & $0 \cdot 131$ & & 0.339 & \\
\hline Mineralization potential & $0.091^{F}$ & & $0.078^{F}$ & & n.s. & \\
\hline Microbial biomass- $\mathrm{N}$ & n.s. & & $0.101^{\mathrm{F}}$ & & n.s. & \\
\hline \multicolumn{7}{|c|}{ Particle-size $N$ and $C$} \\
\hline Sand & n.s. & $0.096^{\mathrm{B}}$ & $0 \cdot 131^{\mathrm{E}}$ & $0 \cdot 109^{B}$ & n.s. & $0 \cdot 166^{\mathrm{B}}$ \\
\hline Silt & n.s. & $0.039^{B}$ & $0 \cdot 109^{E}$ & $0.078^{B}$ & n.s. & $0.237^{B}$ \\
\hline Clay & $0 \cdot 103^{E}$ & $0.057^{B}$ & n.s. & $0.039^{B}$ & n.s. & $0.062^{\mathrm{B}}$ \\
\hline \multicolumn{7}{|c|}{ Density-size $N$ and $C$} \\
\hline Light fraction $\left(<2 \mathrm{Mg} \mathrm{m}^{-3}\right)$ & $0 \cdot 188^{\mathrm{E}}$ & $0 \cdot 365^{C}$ & $0 \cdot 183^{E}$ & $0 \cdot 194^{C}$ & $0.482^{\mathrm{E}}$ & $0 \cdot 293^{C}$ \\
\hline Heavy fraction $\left(>2 \mathrm{Mg} \mathrm{m}^{-3}\right)$ & $0.053^{E}$ & $0.033^{C}$ & $0 \cdot 101^{\mathrm{E}}$ & $0.026^{C}$ & $0.237^{E}$ & $0 \cdot 143^{C}$ \\
\hline \multicolumn{7}{|c|}{ Whole soil $N$ and $C$} \\
\hline & $0.061^{\mathrm{D}}$ & $0.065^{A}$ & $0.115^{\mathrm{D}}$ & $0.080^{A}$ & $0.275^{\mathrm{D}}$ & $0.180^{A}$ \\
\hline
\end{tabular}

A Dalal and Mayer (1986b). B Dalal and Mayer (1986c). C Dalal and Mayer (1986d).

D Dalal and Mayer (1986e). E Dalal and Mayer (1987a). F Dalal and Mayer (1987b). G n.s., not significant.

Oven $\mathrm{N}$ values were poorly correlated with the period of cultivation in most soils and with other available $N$ indices, although Gianello and Bremner (1986) reported that oven $\mathrm{N}$ values were closely correlated with anaerobic and aerobic mineralizable $\mathrm{N}$ in 30 lowa soils.

Nitrate- $N$ contents in these soils were generally measured at the end of the summer fallow period which is at the time of planting of winter cereals. 
Therefore, this $\mathrm{N}$ index should have reflected the $\mathrm{N}$ mineralization rates during the fallow and, hence, the effect of period of cultivation in these soils. This was so in Thallon and Riverview soils where mineralizable (anaerobic) $\mathrm{N}$ levels were the lowest (Table 1) and $\mathrm{N}$ mineralized during fallow was probably utilized by the succeeding crop. In other soils, especially Langlands-Logie and Billa Billa soils, the amount of $\mathrm{N}$ mineralized exceeded crop $\mathrm{N}$ uptake in a few initial years of cultivation and thus nitrate- $\mathrm{N}$ accumulated in the soil profile (Billa Billa, Fig. 2) and/or leached beyond the root zone or below $1 \cdot 2 \mathrm{~m}$ depth (Langlands-Logie; R. C. Dalal, unpublished data). Dalal (1984a) reported that, in Billa Billa soil, $\mathrm{NO}_{3}^{-}-\mathrm{N}$ accumulated at the rate of $29 \mathrm{~kg} \mathrm{~N}^{-1}$ year-1 at $0 \cdot 6-1 \cdot 2 \mathrm{~m}$ depth in the first 7-12 years of cultivation. After 7-12 years of cultivation and cropping of these soils, accumulated $\mathrm{NO}_{3}^{-}-\mathrm{N}$ in the soil profile declined (Fig. 2), probably because crop $\mathrm{N}$ uptake either exceeded mineralized $\mathrm{N}$ and/or accumulated $\mathrm{NO}_{3}^{-}-\mathrm{N}$ leached beyond the root zone (Wetselaar and Norman 1960; Waring and Teakle 1960; Catchpoole 1987).

\section{Dry Matter Yield and Nitrogen Uptake in Relation to Available Nitrogen Indices}

It was found necessary to adjust the dry matter and grain yields and $\mathrm{N}$ uptake for 'site' or 'soil series' differences (via covariate variables) to improve the relationship with the available $\mathrm{N}$ indices. This was not required for the yield data from the glasshouse experiment because of the uniform environmental conditions (temperature, moisture) for plants grown in different soils. Relationships between field dry matter yields to available $\mathrm{N}$ indices, although similar within a soil series, differed significantly among soil series, mainly because of environmental differences among the soil series (Dalal and Mayer 1986a). Moisture conditions were probably only marginally, if at all, limiting to crop growth in 1983. Temperature differences among the six soil series were probably important since temperature affects both crop growth and $\mathrm{N}$ mineralization. For example, mean monthly temperatures for October were $19.8^{\circ} \mathrm{C}$ for Dalby (Waco and Cecilvale soil series) and $21.4^{\circ} \mathrm{C}$ for Surat (Riverview soil series). Dry matter yield and $\mathrm{N}$ uptake of wheat obtained in the glasshouse experiment and adjusted field dry matter and grain yields and $\mathrm{N}$ uptake were significantly correlated with anaerobic and aerobic mineralizable $\mathrm{N}$ and total N. Chalk and Waring (1970), Stanford (1982) and Sahrawat (1984) have obtained good correlations between plant $\mathrm{N}$ uptake in pots and a number of available $\mathrm{N}$ indices including total $\mathrm{N}$ and organic $\mathrm{C}$. Organic $\mathrm{C}$ was compared with $\mathrm{N}$ availability indices in this study because it can be rapidly determined and it is closely correlated with total $\mathrm{N}$ contents of the six soil series studied (Dalal and Mayer 1986e). However, it predicted crop $\mathrm{N}$ uptake less precisely than anaerobic and aerobic mineralizable $\mathrm{N}$ and total $\mathrm{N}$.

Inclusion of $\mathrm{NO}_{3}^{-}-\mathrm{N}$ with $\mathrm{N}$ availability indices improved the correlations with dry matter yield and $\mathrm{N}$ uptake considerably. This is to be expected, since $\mathrm{N}$ availability indices, anaerobic and aerobic mineralizable $\mathrm{N}$, autoclave $\mathrm{N}$ and oven $\mathrm{N}$ were measured in soil samples collected at or just before planting the cereals. The best prediction of $\mathrm{N}$ uptake, both in the glasshouse experiment and field experiment, was obtained when anaerobic mineralizable $\mathrm{N}$ and $\mathrm{NO}_{3}^{-}-\mathrm{N}$ were considered together. For field $\mathrm{N}$ uptake, anaerobic mineralizable $\mathrm{N}$ down to $0.3 \mathrm{~m}$ depth and $\mathrm{NO}_{3}^{-}-\mathrm{N}$ down to $0.6 \mathrm{~m}$ depth were superior to other $\mathrm{N}$ 
availability indices. Nitrate- $\mathrm{N}$ down to $0.6 \mathrm{~m}$ depth has been extensively used in Canada (Soper et al. 1971) and the Darling Downs, Queensland, (Strong 1981) to predict $\mathrm{N}$ fertilizer requirements for cereals, although Onken and Sunderman (1972) and Taylor et. al. (1988) found no improvement in the prediction of grain yields when $\mathrm{NO}_{3}^{-}-\mathrm{N}$ concentrations below $0.3 \mathrm{~m}$ depths were considered. The usefulness of considering mineralizable $\mathrm{N}$ with $\mathrm{NO}_{3}^{-} \mathrm{N}$ for predicting dry matter and grain yields and $\mathrm{N}$ uptake has been demonstrated by a number of workers (Geist et al. 1970; Campbell 1978). Geist (1977) also found that anaerobic mineralizable $\mathrm{N}$ predicted $\mathrm{N}$ uptake better than total $\mathrm{N}$.

Table 5. Cultivation period before crop nitrogen uptake declined to $90 \%$ of the maximum uptake

\begin{tabular}{ccccc}
\hline $\begin{array}{c}\text { Nitrogen } \\
\text { availability } \\
\text { index }\end{array}$ & $\begin{array}{c}\text { Sampling } \\
\text { depth } \\
(\mathrm{m})\end{array}$ & \multicolumn{2}{c}{$\begin{array}{c}\text { Cultivation period at 90\% of max. yield (years) } \\
\text { Waco }\end{array}$} & $\begin{array}{c}\mathrm{A} \\
\text { Langlands-Logie }\end{array}$ \\
\hline Anaerobic & $0-0 \cdot 1$ & $5 \cdot 3(3 \cdot 8)^{\mathrm{B}}$ & $8 \cdot 3(6 \cdot 2)$ & $2 \cdot 5(1 \cdot 6)$ \\
mineralizable $\mathrm{N}$ & $0-0 \cdot 3$ & $10 \cdot 2(8 \cdot 3)$ & $-(16 \cdot 9)$ & - \\
Total N & $0-0 \cdot 1$ & $0 \cdot 7(0)$ & $10 \cdot 4(4 \cdot 4)$ & $1 \cdot 2(0)$ \\
\hline
\end{tabular}

A Calculated from the values of available $\mathrm{N}$ indices estimated from the quadratic relationship between crop $\mathrm{N}$ uptake and $\mathrm{N}$ availability index (Table 3 ) and the exponential relationship between anaerobic mineralizable $\mathrm{N}$ and period of cultivation (Table 2) and between total $\mathrm{N}$ and period of cultivation (Table 4, Dalal and Mayer 1986e).

$B$ Values in parentheses are derived from the glasshouse experiment.

Estimates of anaerobic mineralizable $\mathrm{N}$ and total $\mathrm{N}$ levels required for $90 \%$ of maximum dry matter yield varied between glasshouse and field experiments (Table 3). By assuming that crop total $\mathrm{N}$ uptake reflected soil $\mathrm{N}$ supply better than other crop parameters, the maximum periods of cultivation and cropping required for crop $\mathrm{N}$ uptake to decline to $90 \%$ of the maximum uptake were $2 \cdot 5$ $(5 \cdot 1,0-2 \mathrm{~m}), 10 \cdot 2$ and $16 \cdot 9$ years for Cecilvale, Waco and Langlands-Logie soils, respectively (Table 5). Leslie and Hart (1967) also suggested that crop responses to added $\mathrm{N}$ were less likely to occur during the first 5-15 years of cultivation of central Darling Downs soils. It should be emphasized that these conclusions would be modified if crop growth is limited by soil water, which happens frequently in the semi-arid environment, or if crops and soil management practices are altered.

It is concluded that mineralizable $\mathrm{N}$ declined in all soils with the period of cultivation and, together with $\mathrm{NO}_{3}^{-}-\mathrm{N}$ at planting, reflected nitrogen supplying capacity of the soils better than other available $N$ indices (autoclave $N$, oven $\mathrm{N}$ and total $\mathrm{N}$ ) and organic $\mathrm{C}$. Since anaerobic mineralizable $\mathrm{N}$ can usually be measured in a shorter period than aerobic mineralizable $\mathrm{N}$ and it requires less exacting experimental conditions (such as moisture and aeration) than the latter, anaerobic mineralizable $\mathrm{N}$ is preferred as an available $\mathrm{N}$ index of soil.

\section{Acknowledgments}

The authors thank R. Coonan, J. Glasby, A. Pumfrey and P. Henderson for technical assistance and $\operatorname{Dr} B$. J. Bridge and the reviewers for a number of suggestions to improve the presentation of the paper. 


\section{References}

Best, E. K. (1976). An automated method for the determination of nitrate-nitrogen in soil extracts. Queensl. J. Agric. Anim. Sci. 33, 161-6.

Campbell, C. A. (1978). Soil organic C, nitrogen and fertility. In 'Soil Organic Matter'. (Eds M. Schnitzer and S. U. Khan.) pp. 173-271. (Elsevier: New York.)

Campbell, C. A., and Souster, W. (1982). Loss of organic matter and potentially mineralisable nitrogen from Saskatchewan soils due to cropping. Can. J. Soil Sci. 62, 651-6.

Catchpoole, V. R. (1987). Soil nitrate profiles and $\mathrm{N}$ balances under five monocultures on a clay soil. In 'International Symposium on Advances in Nitrogen Cycling in Agricultural Ecosystems'. (Ed. J. Wilson.) pp. 16-17. (CSIRO Aust. Div. Tropical Crops and Pastures: Brisbane, Queensland.)

Chalk, P. M., and Waring, S. A. (1970). Evaluation of rapid tests for assessing nitrogen availability in wheat soils. I. Correlation with plant indices of availability obtained in pot culture. Aust. J. Exp. Agric. Anim. Husb. 10, 298-305.

Crooke, W. M., and Simpson, W. E. (1971). Determination of ammonium in Kjeldahl digests of crops by an automated procedure. J. Sci. Food Agric. 22, 9-10.

Dalal, R. C. (1984a). Chronosequential depth distribution of nitrate in cultivated grey and brown clays under semi-arid environment. Proc. 2nd National Soils Conf. Brisbane, p. 222.

Dalal, R. C., and Mayer, R. J. (1986a). Long-term trends in fertility of soils under continuous cultivation and cereal cropping in southern Queensland. l. Overall changes in soil properties and trends in winter cereal yields. Aust. J. Soil Res. 24, 265-79.

Dalal, R. C., and Mayer, R. J. (1986b). Long-term trends in fertility of soils under continuous cultivation and cereal cropping in southern Queensland. II. Total organic carbon and its rate of loss from the soil profile. Aust. J. Soil Res. 24, 281-92.

Dalal, R. C., and Mayer, R. J. (1986c). Long-term trends in fertility of soils under continuous cultivation and cereal cropping in southern Queensland. III. Distribution and kinetics of soil organic carbon in particle-size fractions. Aust. J. Soil Res. 24, 293-300.

Dalal, R. C., and Mayer, R. J. (1986d). Long-term trends in fertility of soils under continuous cultivation and cereal cropping in southern Queensland. IV. Loss of organic carbon from different density fractions. Aust. J. Soil Res. 24, 301-9.

Dalal, R. C., and Mayer, R. J. (1986e). Long-term trends in fertility of soils under continuous cultivation and cereal cropping in southern Queensland. V. Rate of loss of total nitrogen from the soil profile and changes in carbon-nitrogen ratios. Aust. J. Soil Res. 24, 493-504.

Dalal, R. C., and Mayer, R. J. (1987a). Long-term trends in fertility of soils under continuous cultivation and cereal cropping in southern Queensland. VI. Loss of total N from different particle-size fractions. Aust. J. Soil Res. 25, 83-93.

Dalal, R. C., and Mayer, R. J. (1987b). Long-term trends in fertility of soils under continuous cultivation and cereal cropping in southern Queensland. VII. Dynamics of nitrogen mineralization potentials and microbial biomass. Aust. J. Soil Res. 25, 461-72.

Dalal, R. C., Sahrawat, K. L., and Myers, R. J. K. (1984b). Inclusion of nitrate and nitrite in the Kjeldahl nitrogen determination of soils and plant materials using sodium thiosulphate. Commun. Soil Sci. Plant Anal. 15, 1453-61.

Draper, N. R., and Smith, H. (1966). 'Applied Regression Analysis.' (Wiley: New York.)

Geist, J. M. (1977). Nitrogen response relationships of some volcanic ash soils. Soil Sci. Soc. Am. J. 41, 996-1000.

Geist, J. M., Reuss, J. O., and Johnson, D. D. (1970). Prediction of nitrogen fertiliser requirements of field crops. II. Application of theoretical models to malting barley. Agron. J. 62, 385-9.

Gianello, C., and Bremner, J. M. (1986). A simple chemical method of assessing potentially available organic nitrogen in soil. Commun. Soil Sci. Plant Anal. 17, 195-214.

Haas, H. J., Evans, C. E., and Miles, E. F. (1957). Nitrogen and carbon changes in Great Plains soil as influenced by cropping and soil treatments. Tech. Bull. U.S. Dep. Agric. Washington, No. 1164.

Keeney, D. R. (1982). Nitrogen-availability indices. In 'Methods of Soil Analysis'. (Part 2, 2nd Edn.) (Ed. A. L. Page.) pp. 711-33. (Am. Soc. Agron.: Madison, Wisc.)

Leslie, J. K., and Hart, J. (1967). Key for using nitrogen fertiliser in grain crops. Queensl. Agric. J. 93. 331-4. 
Onken, A. B., and Sunderman, H. D. (1972). Applied and residual nitrate-nitrogen effects on irrigated grain sorghum yield. Soil Sci. Soc. Am. Proc. 36, 94-7.

Sahrawat, K. L. (1984). Nitrogen availability indexes for submerged rice soils. Adv. Agron. 36, 415-51.

Smith, S. J., and Stanford, G. (1971). Evaluation of a chemical index of soil nitrogen availability. Soil Sci. 111, 228-32.

Soper, R. J., Racz, G. J., and Fehr, P. I. (1971). Nitrate nitrogen in the soil as a means of predicting fertilizer requirements of barley. Can. J. Soil Sci. 51, 45-9.

Stanford, G. (1982). Assessment of soil nitrogen availability. In 'Nitrogen in Agricultural Soils'. (Ed. F. J. Stevenson.) pp. 651-88. (Am. Soc. Agron.: Madison, Wisc.)

Stanford, G., and Smith, S. J. (1972). Nitrogen mineralization potentials of soils. Soil Sci. Soc. Am. Proc. 36, 465-72.

Strong, W. M. (1981). Nitrogen requirements of irrigated wheat on the Darling Downs. Aust. J. Exp. Agric. Anim. Husb. 21, 424-31.

Taylor, A. C., Lill, W. J., and MCNeill, A. A. (1988). Importance of mineral nitrogen in the subsoil to yield and uptake of nitrogen by wheat in southern New South Wales. Aust. $J$. Exp. Agric. 28, 215-22.

Waring, S. A., and Bremner, J. M. (1964). Ammonium production in soil under waterlogged conditions as an index of nitrogen availability. Nature 201, 951-2.

Waring, S. A., and Teakle, L. J. H. (1960). Fertility investigations on the black earth wheatlands of the Darling Downs, Queensland. III. Mineral nitrogen in the soil and its relation to the wheat crop. Aust. J. Agric. Res. 11, 27-41.

Wetselaar, R., and Norman, M. J. T. (1960). Recovery of available soil nitrogen by annual fodder crops at Katherine, N.T. Aust. J. Agric. Res. 11, 693-704. 